FRAY RAMÓN PANÉ, EL PRIMER EXTIRPADOR DE IDOLATRÍAS

Fray Ramón Pané, First Extirpator of Idolatry

\title{
Marguerite Cattan*
}

\section{Resumen}

Durante el segundo viaje de Colón, Ramón Pané llegó a la isla de La Española donde convivió entre los nativos y escribió un tratado sobre sus creencias y rituales. Su Relación acerca de las antigüedades de los indios terminada en 1498 es de gran valor histórico y por su labor el autor ha sido celebrado como el primer etnógrafo y etnólogo de América. Sin embargo, Pané ha sido insuficientemente explicado por la mayor parte de los académicos y no ha sido reconocido por lo que más fue, un extirpador de idolatrías. El presente trabajo analiza los rasgos de extirpador que el autor ostenta en esta Relación y que, a su vez, hace de su obra una muestra inaugural de las campañas antiidolátricas en el Nuevo Mundo.

Palabras clave: Pané, Relación, Extirpación de idolatrías, Conquista de América.

\begin{abstract}
During the second voyage of Columbus, Ramón Pané arrived to the island of Hispaniola where he lived among the natives and wrote a treatise on their beliefs and rituals. His Relación acerca de las antigüedades de los indios, completed in 1498, is of great historical value and the author has been celebrated as the first American anthropologist and ethnologist. However, Pané has been insufficiently explained by the majority of scholars. The friar has not been recognized for what he most was, an extirpator of idolatry. This paper analyzes the characteristics of extirpator which the author shows in his Relación which, in turn, makes his work an innaugural sample of the anti-idolatry campaigns in the New World.
\end{abstract}

Key words: Ramón Pané, Extirpation of idolatry, Conquest of America.

\section{INTRODUCCIÓN}

Fray Ramón Pané acompañó a Cristóbal Colón durante su segundo viaje a las Indias en 1493, se asentó en la isla de La Española y convivió entre los nativos aprendiendo su lengua. Hacia 1498 terminó de escribir un tratado sobre las creencias de los naturales de las recién encontradas tierras, obra emprendida ante el pedido del almirante. Su Relación acerca de las antigüedades de los indios es una corta obra de un gran valor histórico y literario, por ser uno de los primeros textos escritos por un europeo en el Nuevo Mundo. Su valor antropológico es apreciado desde 1906 cuando Bourne escribe un ensayo sobre los comienzos de la antropología americana y apunta que la colección de ceremonias y mitos recolectada por Pané se trata del first treatise ever written in the field of American antiquities, but to this day remains our most 
authentic record of the religion and folklore of the long since extinct Tainos ${ }^{1}$. Por ello, algunos críticos han considerado el texto de Pané la "piedra angular" de los estudios etnológicos en el hemisferio occidental (Arrom, Estudio preliminar, xi).

Por su gran labor, este fraile ha sido condecorado por los estudiosos del tema con el epíteto de "el primero": el primer etnógrafo y etnólogo de América, el primer misionero, el primer catequista y maestro de los indios, el primer europeo en hablar una lengua de América, el primer autor de un texto escrito en América, y la lista continúa. Sin embargo, Ramón Pané ha sido insuficientemente explicado por la mayor parte de los académicos. El fraile jerónimo no ha sido reconocido por lo que más fue, un extirpador de idolatrías comprometido con sonsacar las creencias taínas y erradicarlas. Por tanto, se debe añadir un título más a este temprano misionero: el primer extirpador de idolatrías.

No resulta novedoso para el investigador del período colonial constatar que el objetivo de la "extirpación" está enraizada en lo profundo de los agentes de la evangelización, en la mayoría de los clérigos y de los misioneros de la época. No obstante, muchos de los estudiosos se valen de la obra de Pané como un tratado etnográfico y muestran gran interés en analizar los mitos incluidos. Entre ellos, Arrom $(1988,1992)$ los explica dentro del universo taíno, López-Maguiña (1992) analiza su simbolismo y López-Baralt (1992) los compara con otros mitos amerindios, sobre todo con los de la selva amazónica. Lamentablemente, algunos olvidan considerar -o mencionar- el objetivo que el autor tuvo para recolectar dichos mitos: erradicarlos. Inclusive, hay quienes proponen el texto de Pané como representativo e inaugural tanto del discurso etnográfico colonial como de la Modernidad (Solodkow, 238) y que anticipa las corrientes del momento con su propuesta de una nueva antropología dialógica o polifónica que reclama un espacio para la voz del Otro (López-Baralt, Fray Ramon Pané, 73).

Sin embargo, la herencia historiográfica y etnográfica de la obra de fray Ramón debe leerse considerando su lupa de la realidad. Es importante leer los escritos del siglo XVI, como advierte Adorno (2007), más como relatos polémicos o moralistas con fines persuasivos que como historia objetiva. En otro lugar he establecido que Ramón Pané es producto de un mundo hegemónico que responde a la cultura oficial y su obra se caracteriza por una ideología monológica donde las ideas correctas y significativas se centran en la conciencia del autor y su visión del mundo (Cattan, 2013). A lo largo de la Relación el pensamiento hegemónico cristiano del autor se representa y se afirma de diversos modos sosteniendo una idea única: todo lo ajeno al cristianismo es idolatría y debe ser negado.

Partiendo de esa noción, me gustaría ampliar en el presente artículo el modo en que el autor hace prevalecer su punto de vista en cuanto al tema de su obra: las idolatrías de la isla La Española; y al mensaje que desea transmitir: la necesidad de

\footnotetext{
${ }^{1}$ La cita fue tomada de una reseña hecha por F. W. Hodge al ensayo de Edward Gaylord Bourne, "Columbus, Ramon Pane and the Beginnings of American Anthropology".
} 
erradicarlas para lograr la evangelización de los pobladores. Por consiguiente, quisiera mostrar que esta relación de 1498 ostenta propiedades características de un tratado de extirpación de idolatrías y que, por tanto, debe considerarse como una muestra inaugural de las campañas antiidolátricas en el Nuevo Mundo. Más antes, es necesario revisar el momento histórico y el contexto religioso alrededor de Ramón Pané y su obra.

\section{FRAY RAMÓN PANÉ, EL ELEGIDO}

Trece fueron los clérigos que partieron al Nuevo Mundo en el segundo viaje de Colón. Entre estos, los Reyes Católicos nominaron como nuncio del Papa al padre Boyl con el fin de atraer a los nativos hacia la fe católica (León Guerrero, Los compañeros, 84). León Guerrero provee una lista con los nombres de diez de ellos y las órdenes a las que pertenecían (Los compañeros, Apéndice III). Sin embargo, no ha sido determinado quiénes de los frailes fueron elegidos por los monarcas, nominados por sus órdenes religiosas, enrolados por Colón o que voluntariamente se embarcaron hacia las nuevas tierras. Este es un número considerable de religiosos en comparación con el primer viaje en el que "ningún sacerdote figuraba entre los compañeros de Colón" (Dussel, 91). Pero la situación había cambiado, Colón encontró tierras antes desconocidas y el papa Alejandro VI en su primera Bula Inter caetera otorgaba primacía sobre estas tierras a los Reyes Católicos con la condición y obligación de llevar la verdadera religión a los infieles:

os mandamos en virtud de santa obediencia que haciendo todas las debidas diligencias del caso, destinéis a dichas tierras e islas varones probos y temerosos de Dios, peritos y expertos para instruir en la fe católica e imbuir en las buenas costumbres a sus pobladores y habitantes (Bula inter caetera, en línea).

Esta ordenanza a los soberanos españoles recaía sobre su virrey y gobernador de las islas y de la tierra firme de las Indias: el almirante Cristóbal Colón, quien debía asegurarse que las buenas costumbres fueran inculcadas entre los habitantes de las nuevas tierras. En particular la Corona española estuvo interesada en la religión nativa para medir lo difícil que les sería convertirlos al cristianismo (González Echevarría, 144). Un primer paso para instruir la fe católica era verificar si los nativos tenían idolatrías.

Si bien Colón aseguró en su carta de 1493 a los reyes que en "ninguna parte d'estas islas e conocido en la gente d'ellas seta ni idolatría"; y un año después seguía afirmando lo mismo, "porqu'es verdad que ninguna secta ni idolatría no tienen ni hazen conçentos" (Colón, en línea). A la vez, el almirante comenzó a trabajar para saber

si tenían las gentes desta Isla secta alguna que oliese á clara idolatría , y que no lo había podido comprender, y que por esta causa había mandado á un catalán que había tomado hábito de ermitaño, y le llamaban fray Ramón, hombre simple y de buena intención, que sabía algo de la lengua de los indios, que 
inquiriese todo lo que más pudiese saber de los ritos, y religión, y antigüedades de las gentes desta Isla y las pusiese por escrito (Las Casas, 435).

Así, fray Ramón Pané fue nominado para averiguar si los nativos tenían alguna "secta". Ahora, entre trece eclesiásticos dispuestos a llegar a tierras antes desconocidas con el fin de salvar almas, habría que preguntarse por qué este fraile fue el elegido para recolectar información sobre las creencias e idolatrías de los indios. La elección de Pané como autor de un importante informe es cuestionable, sobre todo si aceptamos la aseveración del padre Las Casas que fray Ramón era un "hombre simple" y que meramente "hizo lo que allí pudo, según su poca facultad" (Apéndice, 436). A esta afirmación se añade la propia declaración de fray Ramón en la que se califica como un "pobre ermitaño de la Orden de San Jerónimo" (3).

Dichas afirmaciones tienen una posible explicación. Por un lado, la aseveración de simpleza del fraile no necesariamente implica carencia de intelecto o conocimientos, es decir, poca facultad. La sencillez que demostraba fray Ramón es una condición de su orden religiosa, la que requiere que sus miembros no hagan ostentación de habilidad ni ingenio. Por tanto, esta apreciación del padre Las Casas puede ser una referencia a la humildad que un clérigo jerónimo debe profesar:

con el santo hábito se profesa: mucha HUMILDAD y menosprecio de sí mismo. Lo que busca la Orden de San Jerónimo no es que el monje sea muy docto, ni haga ostentación de habilidad, memoria, ingenio, sino como muy santo se precie de callado, humilde, obediente $\mathrm{y}$, aun a veces, ignorante, porque la obediencia, en siendo resabida, pierde mucho, o lo pierde todo [sic] (Orden de San Jerónimo, en línea).

Además, la autocalificación de Pané como "pobre" y "ermitaño" son también condiciones que contemplan los frailes de la Orden de San Jerónimo, pero que no niegan el acceso al estudio. Esta es una orden calificada de "ermitaños", hombres retirados con mucho aprecio a la soledad y al silencio, de tendencia contemplativa, asidua oración y espíritu de penitencia, están consagrados a imitar la vida y espiritualidad de su santo patrono, Jerónimo de Estridón. Sin embargo, la búsqueda de soledad, humildad y simpleza de ningún modo hace que un monje jerónimo sea un hombre ignorante o simple de entendimiento, pues dicha Orden "no desprecia los ESTUDIOS ni los DONES NATURALES, antes bien los fomenta y estimula si van orientados, primariamente, a que el monje se una más y mejor a Dios $\mathrm{y}$, secundariamente, al provecho y utilidad de los demás [sic]" (Orden de San Jerónimo, en línea).

${ }^{2}$ El 18 de octubre de 1373 el papa Gregorio XI concede una bula aprobando la Ordo Sancti Hieronymi: "se podía recoger todos los Hermitaños que estavan esparcidos por Castilla... Concediole tambien facultad al mismo Prior, para que recibiesse a la profesion de la Orden de San Geronimo, que nuevamente restaurava a todos aquellos hermanos Hermitaños de su congregación. Y a que esta profession se hiziesse según la regla de S. Agustín” (De Sigüenza, 1907:32). La bula papal aprobaba la Orden dándoles como norma de vida la Regla de San Agustín y permitiéndoles llamarse frailes o ermitaños de San Jerónimo. 
Es cierto que la Relación de Pané es una obra corta y sencilla. No obstante, su "estilo monótono y a menudo pedestre" (Arrom, Estudio preliminar, xxiii) puede deberse a que esta es una traducción de traducciones, mediaciones que pueden haber afectado su estilo original ${ }^{3}$. Añadamos a ello el hecho de que Pané transcribió apremiado, a veces, como él mismo afirma, sin suficiente papel (15) y no escribió en su lengua nativa, el catalán, sino en castellano. Por tanto, la poca facultad advertida en el fraile puede ser producto de la premura de su tarea y posibles limitaciones con la lengua española.

Es difícil concebir que un clérigo no calificado fuese encomendado a la empresa de recolectar y transcribir creencias religiosas de las recién encontradas tierras. Colón debió conjeturar que fray Ramón tenía la capacidad para cumplir la tarea delegada, pues esta implicaba, además, aprender la lengua nativa para llevar a cabo la misión. El almirante consideraba que para instruir la fe católica, el primer paso era conocer la lengua nativa, como lo afirmó en su carta a los Reyes Católicos de 1493: "lo torno a dezir y digo otra vez, que otra cosa no me falta para que sean todos christianos salvo no se lo saber dezir ni predicar en su lengua" (Colón, Carta a los Reyes Católicos, en línea). Por tanto, una razón de la elección de Pané pudo deberse a que este fraile había aprendido en poco tiempo la lengua local.

Su nominación, por otra parte, pudo proceder de un mandato de la Corona, ya que los Reyes Católicos tuvieron un trato preferencial con la orden del fraile. Esto se debió a que la Orden de San Jerónimo era una orden religiosa solo ibérica, que sólo se implantó en España y Portugal, y que estuvo muy vinculada a las monarquías reinantes en ambos países. Esta orden fue distinguida por los monarcas de los reinos hispánicos ante cualquier otra familia religiosa; distinción que se manifestó en el trato que mantuvieron los distintos reyes con la orden, en la confianza y el aprecio con el que distinguieron muchos a sus miembros (Campos y Fernández, 113).

Los monasterios jerónimos fueron con frecuencia elegidos por los Reyes Católicos para descansar durante sus recorridos por el territorio español, rezar o trabajar. Inclusive varios de ellos contaban con aposentos acondicionados para los monarcas. Los reyes encontraron en dichos monasterios un lugar de retiro y consuelo espiritual durante los momentos de luto, y el lugar de descanso en los viajes por el reino (Rodríguez Luna, 938-939). Y fue en una sede jerónima, San Jerónimo de la Murtra en Badalona (Barcelona), en la que los reyes Isabel y Fernando se encontraban aposentados con su corte cuando, en abril de 1493, dieron audiencia a Cristóbal Colón

\footnotetext{
${ }^{3}$ El manuscrito original, hasta hoy perdido, fue revisado en la época por Mártir de Anglería (1989) y Bartolomé de las Casas quienes parafrasearon partes del escrito de Pané en sus obras. La única transcripción completa del texto del fraile la hizo Fernando Colón, la que incluyó en la obra que dedicó a su padre: Historia del Almirante don Cristóbal Colón. La obra del hijo de Colón resultó ser también otro manuscrito perdido. Así, el conocimiento del texto de Fernando Colón $-\mathrm{y}$, con él, el manuscrito de Pané- nos llega vía una traducción al italiano hecha por Alfonso de Ulloa en 1571.
} 
tras la llegada de su primer viaje ${ }^{4}$. Ramón Pané era fraile de aquel monasterio ${ }^{5}$. Es probable que durante esa visita el almirante y Pané se conocieron. Sin embargo, como señalé con anterioridad, no hay información concreta sobre quién nominó a fray Ramón para participar en el nuevo viaje de Colón.

Existen claros vínculos de los monarcas con esta orden y, por extensión, con uno de sus miembros, fray Ramón. La elección de Pané para esta específica misión no se puede considerar un acto casual, sino un hecho deliberado por la magnitud de la empresa: aprender la lengua nativa y escribir un informe sobre las idolatrías. Ambos, pasos requeridos para lograr la cristianización de los pobladores del Nuevo Mundo que, al fin y al cabo, era el pretendido fin de la colonización. El fraile jerónimo debió estar calificado para lograrlo, afirmar que "hizo lo que allí pudo" es subestimar su capacidad. Sin embargo, hay que considerar la posibilidad que su elección no se basara únicamente en su competencia, sino en un posible favoritismo.

\section{LA IDOLATRÍA: LA BIBLIA Y AQUINO}

Debemos situar a Ramón Pané y su obra dentro del contexto histórico religioso pre-Tridentino. Su Relación aparece en los primeros momentos de la colonización donde recién se está dando forma al sistema y la polémica sobre los naturales no ha empezado. Nos encontramos todavía un par de décadas antes de que los padres de la Reforma Protestante difundan sus ideas ${ }^{6}$ y, por tanto, lejos del Concilio de Trento y del movimiento Contrarreformista que comenzarán medio siglo después de la obra de Pané. Las campañas de extirpación de idolatrías llevadas a cabo en el Nuevo Mundo serán un resultado de las reformas tridentinas, de las que el tratado del fraile también se halla lejos. El entorno histórico religioso al que se debe mirar es el de los eventos de la Edad Media. Como advierte Dussel, en cuanto a la cristiandad en las Indias occidentales, la estructura del mundo del hispano era la del hombre medieval europeo (80).

La Baja Edad Media —específicamente a fines del siglo XIV y principios del $\mathrm{XV}$ - fue "una etapa de profunda espiritualidad, plagada de iniciativas reformadoras" (Álvarez, 243). Algunas de estas iniciativas llevaron a la formación de nuevos grupos religiosos que aspiraban a una renovada espiritualidad, como fue el establecimiento de la Orden de San Jerónimo, en 1373. Pero también existieron movimientos con demandas reformadoras que fueron tachadas como heréticas, como los movimientos de John Wyclif, por los años 1374 a 1384, y el de Juan Hus, entre 1402 a 1415; ambos considerados los "precursores de la Reforma" (Mitre, 41).

\footnotetext{
${ }^{4}$ En aquel entonces el rey Fernando estaba recuperándose en dicho recinto de un ataque recibido durante una visita a Barcelona. Su atacante, Juan de Cañamares, presunto perturbado mental, fue condenado a muerte.

${ }^{5}$ Hoy sede del Museo Catalunya-América "Ramón Pané".

${ }^{6}$ Martín Lutero publicará sus 95 tesis contra las indulgencias papales en 1517, Juan Calvino recién empezará a actuar hacia 1536.
} 
Si bien el cristianismo medieval estuvo en constante contienda contra las herejías, esto no quiere decir que las idolatrías estuviesen fuera de la mira. No en balde santo Tomás de Aquino dedicó el Volumen 40 de su Summa Theologice (12651274) a la "Superstición e irreverencia". Este volumen se ocupa de los actos que distorsionan la unidad religiosa del hombre y sus deberes para con Dios, entre ellos "La idolatría, la superstición, el sortilegio, la adivinación, la astrología son perversiones de los instintos naturales del hombre religioso. Son las formas en que el hombre extravía sus ritos religiosos a las criaturas o poderes de las tinieblas en vez de luz" (Aquinas xix, trad. mía).

El principio de idolatría y su necesidad de extirpación se manifiesta desde que Dios comandó a Moisés hacer frente a todo signo indebido de adoración: "No haréis para vosotros ídolos, ni esculturas, ni os levantaréis estatua, ni pondréis en vuestra tierra piedra pintada para inclinaros a ellas porque yo soy Jehová vuestro Dios" (Levítico 26:1). Solo el Señor todopoderoso debe recibir la adoración que le corresponde. Latría es el culto que se le rinde con exclusividad y es un acto de devoción y servicio a Dios. Toda adoración dirigida a otro objeto, criatura o entidad que no sea el Creador es errónea e incorrecta y es considerada idolatría. Esta es una falta grave por la injuria que con ella se hace a Dios mismo.

Para el hombre medieval, así como los herejes son infieles también lo son aquellos que adoran a los ídolos. Santo Tomás advierte que tanto la herejía como la idolatría son pecados contra la fe. Siguiendo a san Agustín concluye que cualquier cosa inventada por el hombre para hacer y adorar ídolos o para dar culto a una criatura es supersticioso. Así, la herejía es una especie de incredulidad, pero la idolatría es una especie de superstición (Aquinas, 23). Es dentro de este contexto y con esta perspectiva que el evangelizador llega al Nuevo Mundo.

Por tanto, fray Ramón, obedeciendo la ideología cristiana de la época $-\mathrm{y}$ siguiendo un pensamiento tomista - califica las creencias y prácticas de los habitantes de La Española como supersticiosas afirmando que cada uno de los indios adora a sus ídolos de "un particular modo y superstición" (3). Así, los mitos y ritos taínos que colectará estarán tintados de características extrañas a la fe religiosa y contrarias a la razón en cuanto a la reverencia idolátrica hacia criaturas u objetos, la errónea búsqueda de instrucciones para predecir el futuro, el uso de sustancias embriagantes y las equivocadas prácticas rituales en general.

En las primeras líneas de la Relación el autor anuncia al lector que los nativos de La Española son politeístas y que guardan grandes supersticiones y modos particulares de adoración. El fraile no tarda en identificar a sus dioses como ídolos afirmando que cada uno adora a "los ídolos que tienen en casa, llamados por ellos cemíes" (4). Pané califica ipso facto a las deidades nativas como ídolos partiendo de una amonestación de la Santa Biblia: "todos los dioses de los pueblos son ídolos: mas Jehová hizo los cielos" (Salmo 96:5). Fray Ramón también debió estar familiarizado con los escritos de Aquino, quien advierte que debido a la costumbre común entre los 
paganos de adorar a cualquier tipo de criatura bajo la forma de imágenes, el nombre de idolatría se da a cualquier culto a las criaturas, incluso sin el uso de las imágenes (Aquinas, 25).

El fraile jerónimo se conduce según lo dicta su fe y lo manda su hábito, pues santo Tomás afirma que "la adoración de Dios, latría, es un acto de la virtud de la religión de la que la superstición es un opuesto... la idolatría no es más que la negación de la virtud de la religión" (Aquinas, 19, trad. mía). Guiado por su visión monológica del mundo (Cattan, 223), fray Ramón hace una cuidadosa distinción de la virtud del cristianismo versus la negación del mismo, advirtiendo al lector en su relación sobre las "fabulosas" creencias nativas y concluyendo al final de la misma cómo erradicarlas.

\section{¿PANÉ EXTIRPADOR DE IDOLATRÍAS?}

Primero deseo establecer los límites de la noción de extirpación de idolatrías con la que pretendo trabajar. Debemos entender la extirpación de idolatría como "el principio general de la evangelización según el cual era necesario erradicar los cultos paganos como paso previo a la difusión de la doctrina cristiana. Se trata de un principio básico, universal... [compartido] con otras experiencias evangelizadoras" (García, 1).

Para el propósito del presente estudio no debemos confundir extirpación de idolatrías con una práctica institucionalizada, como la que se desarrollará años después, principalmente en el virreinato del Perú. Más bien como un principio universal del misionero cristiano, donde la práctica de extirpación tiene bases comunes en todas partes de América.

Entre los procedimientos comunes para extirpar idolatrías estaban: (i) el interés en aprender la lengua vernácula para conducir a los nativos a la verdadera fe; (ii) la familiarización con las prácticas idolátricas indígenas, a fin de encontrar los dioses locales, estudiarlos detenidamente, para finalmente atacarlos; (iii) la destrucción de todo signo de culto, como estatuillas, templos, monumentos; (iv) la imposición de penas y castigos públicos a los líderes encargados de oficiar los ritos paganos, a modo de ejemplo; y (v) en ocasiones, el empleo de algunos métodos preventivos como reducir a indios en pueblos para controlar sus prácticas y enviar a los hijos de caciques a colegios para conducirlos a las buenas costumbres. También era común que, en este intento, participaran tanto las autoridades eclesiásticas como civiles. El poder civil se encargaba, sobre todo, de la destrucción de objetos paganos con el fin de dejar el terreno fértil, y en la imposición de los castigos.

El grado y tenacidad con la que se aplicaron estos procedimientos varió según el lugar y el tiempo, pero estuvieron presentes, en general, como parte esencial de la evangelización de América desde los tempranos momentos de la llegada de los primeros religiosos al Nuevo Mundo. Como sabemos, al llegar al Nuevo Mundo Pané dio el primer paso para intentar evangelizar a los taínos: aprender su lengua nativa. En 
las siguientes líneas expongo otros principios de extirpación de idolatría que se manifiestan en la obra de Ramón Pané.

Gruzinski (1995) es uno de los estudiosos que ha tratado el tema de las imágenes y la idolatría en el Nuevo Mundo, él afirma que "no se habla de idolatría ni de idólatras en el texto de Pané" (21). Me permito discrepar con esta opinión. El fraile sí habla de idolatrías, aunque lo hace en una sola ocasión: en el exordio del texto donde avisa que su obra es un tratado sobre "las creencias e idolatrías de los indios, y de cómo veneran a sus dioses" (Pané, 3). Este preámbulo advierte al lector el asunto de su estudio y, por tanto, Pané no necesita reafirmar esta idea nuevamente, porque el contenido mismo de su texto revalida la noción de idolatría entre los naturales de esas tierras. No obstante, si la palabra idolatría no se repite en la Relación, la palabra ídolo aparece en varias ocasiones. Gruzinski asevera al respecto que cuando fray Ramón habla de ídolo "lo hace manifiestamente por pereza al escribir y por comodidad, para luego corregir y poner 'demonio' [...] o para distinguir el zemí del ídolo" (21). No queda claro cuál es la específica distinción que este académico encuentra que Pané realiza entre cemí, ídolo y demonio, muy al contrario el fraile jerónimo equipara estos términos cuando habla de los cemíes refiriéndose a ellos como "ídolos, o por hablar más propiamente aquellos demonios" (Pané, 26).

Dentro de la ideología cristiana no existe distinción entre ídolo y demonio, como lo confirman las diferentes traducciones de la cita bíblica siguiente: Quoniam omnes dii gentium dcemonia; Dominus autem caelos fecit (Salmo 95(96):5). La primera parte de este versículo ha sido traducido del latín de diversas maneras: "Porque todos los dioses de las naciones son demonios", "Porque todos los dioses de los pueblos son ídolos", "Pues todos los dioses de los gentiles son ficción", y "Nada son los dioses de los pueblos" -énfasis mío en todas las instancias-. La equiparación de los ídolos con el demonio es axiomática de la fe cristiana, que ve a los mismos como entes de ficción, es decir, nada, porque es Dios quien ha hecho el cielo.

La aseveración de Gruzinski en cuanto a que Pané hizo una distinción entre ídolo y cemí es refutable. Muy temprano en el texto, el fraile equipara ambos conceptos diciendo que los ídolos son "llamados por ellos [los nativos] cemíes" (Pané, 4). Encuentro que si el fraile privilegia el uso de la palabra cemí en su texto lo hace por dos razones: primero, recalcar el nombre nativo como una advertencia para reconocerlo fácilmente $\mathrm{y}$, por otro lado, lograr un mayor distanciamiento de estos objetos. Fray Ramón distingue la religión pagana de la suya mediante el particular uso de los vocablos taínos para nombrar los objetos y sujetos idólatras. Así, una vez que señala que en La Española a los ídolos se les llaman "cemíes" y a los médicos brujos "behiques", deja de utilizar la palabra castellana en su relación y exclusivamente los identifica con la palabra taína. Es decir, el uso de las palabras ídolo y hechicero (o médico brujo) inscribirían al lector de la época en una realidad reconocible, mientras que el vocablo taíno sugiere una realidad no identificable, distanciando así la religión del Otro de la verdadera religión cristiana. 


\section{RELACIÓN ACERCA DE LAS “FÁBULAS” DE LOS INDIOS}

Los primeros trece capítulos de la Relación están dedicados a los mitos y creencias de los taínos que el autor recolecta de oídas. Alentado por su labor evangelizadora, fray Ramón se familiarizó con el universo religioso taíno al que transcribió en esos capítulos. Sin embargo, según su ideología religiosa cristiana el evangelizador tiene una natural respuesta de alejamiento y desaprobación ante el mundo religioso pagano. Pané logra este distanciamiento añadiendo a la mayoría de los mitos referidos un mismo encabezado: "dicen que".

En otro artículo he hecho mención de cómo el autor establece la diferencia entre la verdad de la fe cristiana y las creencias nativas mediante la metódica utilización de los verbos "dicen" y "creen" para referirse a las creencias taínas. Dichas glosas a los mitos referidos sugieren un mundo creado y falso, restando valor a sus palabras y desautorizando la realidad taína. Prescindiendo de tal encabezado, la relación adquiriría otra lectura: la narración nativa obtendría la calidad de afirmación. Fray Ramón con esa pequeña adición controla la palabra taína, enmarcando sus mitos dentro de los límites de "ficción" versus la "verdad" de la religión cristiana (Cattan, 207).

De acuerdo con la postura ideológica de Ramón Pané las creencias religiosas cristianas son ciertas - la verdad de Dios es alabada en los Salmos - y entran en el campo del saber. Mientras que toda otra creencia no es cierta, solo es supuesta y presumida, y entra en el campo del creer. En otras palabras, sus creencias cristianas se afirmarán mientras que las creencias nativas se negarán — esto es tertium non datur en la que se basa la ideología monológica-

En la Relación mientras las "creencias" están relacionadas a la simplicidad, la ignorancia, la idolatría y lo demoníaco; el "conocimiento" está conectado a la complejidad, la sabiduría y lo divino (López Maguiña, 297). Por consiguiente, el taíno tiene únicamente creencias fabulosas en tanto la cultura hispana es poseedora del conocimiento base del saber. Para fray Ramón el saber es algo de lo que los nativos carecen: no saben leer, ni contar sino hasta diez; no saben el nombre; no saben cuánto tiempo ha transcurrido. La carencia indígena de sapiencia está basada, según Pané, en su desconocimiento de la escritura, ya que "como no tienen letras ni escritura, no saben contar bien tales fábulas" (3). Pero además la insensatez y credulidad de los nativos parte de su ignorancia y, por ello, dichas creencias las "tienen por ciertísima aquella gente ignorante" (39).

La ignorancia para Pané — siguiendo nuevamente un pensamiento tomistaes la principal causa de idolatría nativa. Santo Tomás señala tres causas de la idolatría: el afecto mal dirigido, dando a otro la adoración, ya sea por amor o veneración más allá de la razón; el deleite natural del hombre en la representación de imágenes hábilmente modeladas; y la ignorancia del Dios verdadero y de su esplendor, por lo que se ofrece culto divino a las criaturas de sorprendente belleza y contundencia (Aquinas, 33-35). Es la ignorancia del verdadero Creador lo que mantiene a los 
moradores de aquella isla en un erróneo culto a sus cemíes, pues no tienen "conocimiento de nuestra santa fe" (Pané, 26). Debido a esta ignorancia el pueblo ha sido engañado por sus antepasados, por los caciques y por los behiques (hechiceros).

Entonces, los taínos "dicen", "creen", y "no saben". Mediante estas adaptaciones editoriales, fray Ramón distancia su fe verdadera y cierta de toda otra creencia e ignorancia. Sin embargo, Pané no se limita a glosar palabras en su transcripción, en algunos casos incluye un dictamen sobre las cosas narradas por los nativos al decir, por ejemplo, que están "fuera de juicio" y ni "saben contar bien" sus "fábulas". Para fray Ramón los mitos locales no son nada más que fábulas, es decir, relatos ficticios, inventados e imaginados, que no tienen cordura. El autor aparta la verdad del yo/nosotros versus las ficciones del taíno/ellos.

\section{RELACIÓN ACERCA DEL “DEMONIO” DE LOS INDIOS}

Santo Tomás añade una causa complementaria de la idolatría, la que es el poder demoníaco que se manifiesta ante la humanidad confundida como objetos de culto, dando respuestas mediante ídolos y realizando prodigios ante los ojos de los hombres (Aquinas, 33-35). La fuerza de los poderes demoníacos también está manifiesta en la obra de Pané y es para el autor una razón primordial de la idolatría nativa. En primer lugar, el demonio se revela a los aborígenes por medio de sus cemíes (sus ídolos), de los cuales tienen gran número y de diversas formas.

Unos contienen los huesos de su padre... y de sus antepasados; los cuales están hechos de piedra o de madera... algunos que hablan, y otros que hacen nacer las cosas que comen, y otros que hacen llover, y otros que hacen soplar los vientos. Las cuales cosas creen aquellos simples ignorantes que hacen aquellos ídolos, o por hablar más propiamente, aquellos demonios (Pané 26, énfasis mío).

El demonio también trabaja por medio de los caciques, quienes engañan a su pueblo con poderes falsos y adivinaciones, dan el mal ejemplo con las numerosas mujeres que poseen, pues "suelen tener dos o tres, y los principales, diez, quince y veinte" (Pané 49). Además, son quienes guían al pueblo a la idolatría, pues muchos de los principales de aquella tierra reprenden al que desea "obedecer la ley de los cristianos" (44). Es decir, los caciques impiden la evangelización y, con ello, perpetúan la idolatría favoreciendo a satanás.

Pero sobre todo el maligno actúa mediante los behiques, a los que Pané califica de brujos y hechiceros. Ellos personifican al diablo, pues la hechicería es labor del demonio. Fray Ramón juzga en varias ocasiones las prácticas de los behiques, de los que dice: "hacen muchos engaños" (24). La palabra engaño es continuamente enfatizada por el fraile al describir las actividades rituales de los behiques, pues ellos como el demonio tratan de confundir a los hombres y conducirlos hacia el mal. 
Pané, además, advierte que los behiques se embriagan con cohoba, y el uso de sustancias embriagantes es otro vicio que suele acompañar a la idolatría. El fraile describe cómo el uso de la cohoba en sus ritos paganos conlleva a más actos idólatras, pues los induce a tener visiones, a la práctica de la brujería y al intento de descubrir lo oculto mediante vaticinios del futuro. Santo Tomás avisa que toda adivinación es condenable porque implica la actividad de los demonios, ya sea porque son invocados expresamente para revelar el futuro o porque invaden esas inútiles búsquedas del futuro, a fin de enredar las mentes de los hombres con presunciones vanas. La predicción del futuro conlleva la adoración de las fuerzas demoníacas debido a un pacto con ellos, ya sea tácito o expreso (Aquinas, 43).

Asimismo, los behiques invocan las fuerzas ocultas para sanar cuerpos y en otros actos rituales. Aunque la finalidad sea buena esto es un acto condenado. Tomás de Aquino advierte que el solo hecho de invocar las potencias diabólicas es malo, ya que el demonio, que pretende la condena del hombre, intenta por sus respuestas, aunque sean verdad, conseguir que el hombre confie en él y de este modo llevarlo hacia la pérdida espiritual (49).

El pacto del behique con el diablo se hace evidente en el episodio en que tratan de darle muerte, rompiéndole a palos las piernas y los brazos, sin embargo

vienen muchas culebras de diversas clases, blancas, negras, y de otros muchos colores, las cuales lamen la cara y todo el cuerpo del dicho médico [...] [y] los huesos de las piernas y de los brazos vuelven a unirse y se suelda, y que se levanta y camina poco y se vuelve a su casa (Pané, 30-31).

La presencia del demonio se encuentra tanto en el acto de mantener con vida al hechicero, que es el instrumento de su poder, como en el recurrente hecho de manifestarse mediante el animal de su predilección: la serpiente. Los behiques, dentro del mundo ético-religioso del autor, y con sus prácticas de hechicería, sus falsos prodigios curativos y su invocación a las fuerzas ocultas, personifican al diablo y su interés de confundir a la humanidad y encaminarla al mal.

Aunque el autor hace pocas intromisiones directas en la obra, no encuentra imprescindible hacer aclaraciones sobre el tema que está narrando, porque "a buen entendedor bastan pocas palabras" (48). Sus esclarecimientos no son necesarios en cuanto están sobreentendidos dentro del mundo ético-religioso del lector, al cual el texto va dirigido, que reconoce el poder del demonio en los actos descritos y comprende que toda forma de idolatría es errada.

\section{RELACIÓN ACERCA DE LAS “PRÁCTICAS RITUALES” DE LOS INDIOS}

Pané, en su obra, además de referir los mitos describe las ceremonias y costumbres locales. Sobre todo presta mucha atención en explicar los actos rituales de los behiques, los que reproduce señalando su vestimenta, sus movimientos $\mathrm{y}$, en algunos casos, repitiendo las palabras del hechicero. El extirpador necesita especificar 
en detalle las actividades demoníacas para reconocerlas bien y poder así hacerles frente. Por ello es importante para fray Ramón describir todo pormenor de los actos rituales que practican los behiques. Entre estos menciona cómo se pintan la cara, las canciones que entonan, los bailes que realizan, las sustancias con las que se embriagan, los jugos que preparan y beben, los productos con los que untan sus cuerpos y las purgas y dietas que efectúan.

El autor narra, también, las prácticas rituales de los caciques. Como la de recitar de memoria los mitos y las leyes que tienen "compendiada en canciones antiguas" (24) y que entonan al son de un instrumento llamado mayohabao. También describe cómo hacen sus oraciones estando "un rato con la cabeza baja y los brazos sobre las rodillas; luego alza la cabeza, mirando al cielo y habla" (33). Y cómo, al igual que los behiques, tienen la costumbre de utilizar el "polvo llamado cohoba, aspirándolo por la nariz, el cual embriaga de tal modo que no saben lo que hacen" (26-27).

Asimismo, menciona las costumbres entre las personas comunes como, por ejemplo, el dar de comer a sus cemíes "de lo que ellos comen" y en días solemnes ofrendarles mucho alimento "para que coma de aquello el dicho ídolo" (28). Dice que hacen otras veces ayunos rituales en honor de los cemíes que tienen, para alcanzar victorias sobre sus enemigos o para adquirir riquezas. En ocasiones, cuando muere un enfermo le dan de beber una poción hecha con una hierba "que se llama güeyo" (29), a fin de hacer hablar al muerto y que les indique la causa de su muerte. Relata también que echan a los muertos en grandes hogueras.

La recolección de ritos y costumbres, igual como sucede con los mitos, responde a un intento de familiarización con las prácticas idolátricas locales a fin de identificarlas, estudiarlas detenidamente, para atacarlas y finalmente erradicarlas. El mismo esfuerzo se realizará para conocer a los dioses locales.

\section{RELACIÓN ACERCA DE LOS “DIOSES LOCALES” DE LOS INDIOS}

Para el extirpador es de fundamental importancia reconocer las diferentes deidades que los gentiles adoran con el objetivo de destruirlas, tal como lo dispone Dios: "Y derribaréis sus altares, y quebraréis sus imágenes, y sus bosques consumiréis con fuego: y destruiréis las esculturas de sus dioses, y extirparéis el nombre de ellas de aquel lugar (Deuteronomio 12:3).

Pané, por tanto, realiza una minuciosa labor en averiguar sobre los dioses locales y dedica seis capítulos exclusivamente a esas deidades (además de las varias menciones que hace sobre los cemíes cuando relata los mitos y ritos), además, especifica que algunos son de "piedra de diversas hechuras" (33), los hay de madera y que también son cemíes los cuerpos de los muertos. Asimismo, el autor hace referencia de dónde proceden. Los cemíes de piedra, generalmente, resultan de los objetos "que dicen que los médicos sacan del cuerpo" del enfermo (33). Los ídolos de madera se originan de algún árbol que mueve la raíz, y que luego de hablar con el behique le indica "la forma en que quiere que lo haga" (33). Y, naturalmente, a fin de 
facilitar su detección publica sus nombres y de algunos describe su apariencia. Como "el cemí Opiyelguobirám dicen que tiene cuatro pies, como de perro, y es de madera" (36), el cemí Corocote que tiene dos coronas y el cemí Guabancex que es mujer, diosa del viento y el agua, y está hecho de piedra. Advierte que al cemí principal de la isla se le atribuyen diversos nombres, entre ellos el de Baraguabael. También, Pané refiere las tareas de estos dioses locales, algunos sirven de mensajeros, otros están provistos "de funciones políticas, de propiedades terapéuticas y climáticas, los zemíes tienen sexo, hablan y se mueven" (Gruzinski, 20).

Es una ardua misión la que este fraile efectúa, pues no deja sin mención ninguna de las características para identificar a los ídolos locales por nombre, material, apariencia y función. Procura, también, identificar y describir los lugares de adoración, algunos sin ídolo alguno, como la cueva que "se llama Iguanaboina, y ellos la tienen en mucha estimación, y la tienen toda pintada a su modo, sin figura alguna, con muchos follajes y otras cosas semejantes" (Pané, 20-21). Igualmente, determina otros espacios sagrados para los locales, como el lugar donde van los muertos que "se encuentra a un lado de la isla, que se llama Soraya" (21-22). Incluso menciona el nombre de algunas cuevas, islas y lagunas que aparecen en los mitos. Todos los lugares que nombra son importantes de señalar y ubicar por el poder mágico-religioso que ejercen en la conciencia nativa.

Nuevamente las aclaraciones del autor no están presentes, pues no son necesarias en cuanto está sobreentendido que la veneración a toda imagen u objeto no es más que la negación de la virtud de la religión.

\section{LAS RECOMENDACIONES: MÉTODOS PREVENTIVOS, PENAS Y CASTIGOS}

Mediante su labor en La Española, fray Ramón Pané cumple la misión del extirpador de idolatrías. En primer lugar, ha aprendido la lengua vernácula para conducir a los nativos a la verdadera fe, enseñándoles principalmente "el Padre Nuestro, el Ave María y el Credo y todas las otras oraciones y cosas que son propias de un cristiano" (44). También se ha familiarizado - y familiariza al lector de su relación - con las prácticas idolátricas y los dioses locales, para poder identificarlos con la finalidad de luego atacarlos y erradicarlos. Pero, además, en los últimos tres capítulos de su obra Pané describe su misión y experiencia personal e incluye sus recomendaciones para evangelizar esas tierras.

Sobre métodos preventivos, aunque el autor no sugiere nada de un modo directo, indica que es bueno el uso de ingenio y presenta su propia labor como un buen ejemplo de evangelización. Menciona que él ha logrado la conversión de "toda una casa de gente principal de la sobredicha provincia de la Magdalena" (41). Una familia de diecisiete personas, las que "todas se hicieron cristianas, con darles solo a conocer que hay un Dios, que ha hecho todas las cosas, y creó el cielo y la tierra" (48). Su modo de catequización sugiere que es efectivo enseñar el evangelio a la gente principal, quienes luego darán el buen ejemplo a los demás. Pero, además, 
muestra con su método que es positivo trabajar con una pequeña reducción de nativos, porque es más fácil conducir a la práctica de las buenas costumbres.

En la Relación no se hace mención sobre si hubo alguna destrucción de los signos de culto pagano, ni tampoco se refiere ninguna sanción por tenerlos. Las Casas, sin embargo, refiere que los locales guardaban y celaban los cemíes de los españoles y "cuando sospechaban su venida, los llevaban y escondían por los montes" (439); de lo que se infiere que los recién llegados quitaban estos objetos de culto a los nativos, ya fuese para destruirlos o llevarlos como curiosidades a España. Los cemíes al parecer no fueron destruidos en un primer momento de la conquista, pues, como Gruzinski señala, cuando estos se descubrieron se llevaron al Viejo Mundo como antiguallas y fueron objetos de gran curiosidad e intrigaron mucho, en especial a Pedro Mártir (20-29).

Las penas y castigos se presentan más bien cuando seis nativos profanaron un adoratorio cristiano donde "entraron a la fuerza y tomaron las imágenes y se las llevaron" (Pané, 46). Como consecuencia del acto, estos hombres recibieron un castigo público comandado por Bartolomé Colón, quien "como lugarteniente del virrey y gobernador de las islas formó proceso contra los malhechores y, sabida la verdad, los hizo quemar públicamente" (47). Fray Ramón se limita a referir los eventos sin incluir una apreciación personal sobre el resultado de los mismos, sin embargo, tampoco parece estar en desacuerdo con la sanción dispuesta por las autoridades civiles: la condena a muerte.

El fraile no da muestras de considerar la no violencia cristiana que predica el Evangelio: "No resistáis al mal; antes á cualquiera que te hiriere en la mejilla diestra, vuélvele también la otra" (San Mateo 5:39). En cuanto atañe a los transgresores, más bien parece aceptar la justicia retributiva de ojo por ojo, diente por diente, pues encuentra un "perverso propósito" en los actos de Guarionex y sus vasallos (47) quienes, además de destruir las imágenes cristianas, no descansaron hasta dar "muerte cruel" a los nativos cristianos a quienes califica, en varias instancias, de mártires.

El crimen del cacique Guarionex resulta más condenable, desde una perspectiva ético-cristiana, ya que no solo ordenó el sacrilegio de profanar los objetos del adoratorio cristiano, sino que negó la verdadera fe. Pané relata que Guarionex en un primer momento aceptó en su territorio la evangelización, mas habiendo conocido al Dios verdadero lo negó testarudamente y abandonó su buen propósito de convertirse al cristianismo. Santo Tomás advierte que uno que peca a sabiendas resulta ser más perverso que uno que peca por ignorancia. "Así, es posible que los herejes, que con conocimiento corrompen la fe que antes profesaron, pequen más gravemente que los que adoran ídolos por ignorancia" (Aquinas 31, trad. mía). Si bien la mayoría de los nativos son idólatras, lo son debido a su ignorancia de la verdadera religión $\mathrm{y}$, por tanto, su pecado no es tan grave. Mas el cacique renegado es merecedor de castigo. 
Por ello, Pané no duda en sugerir la aplicación de "fuerza y castigo" para guiar a muchos a la fe. Fray Ramón, de acuerdo con el ideal extirpador de la campaña evangelizadora, es consciente de la necesidad de castigar al idólatra perseverante y finaliza recomendando que aunque hay los que son propensos a creer fácilmente,

con los otros hay necesidad de fuerza y de ingenio, porque no todos somos de una misma naturaleza. Como aquellos que tuvieron buen principio y mejor fin, habrá otros que comenzarán bien y se reirán después de lo que se les ha enseñado; con los cuales hay necesidad de fuerza y castigo (48).

En esta cita el fraile jerónimo demuestra adelantarse a sus tiempos y prever el problema que la evangelización encontrará en los años venideros: conversos que comenzarán bien y se reirán después. Una razón por la que se instituirán con mayor fuerza las campañas de extirpación en el Nuevo Mundo.

Según la ideología ético-cristiana de los clérigos y misioneros de la época, la idolatría es una gran blasfemia contra el Señor, "ya que priva a Dios de la unidad de su dominio, y por sus hechos niega la fe" (Aquinas, 31, trad. mía) y, por tanto, se debe extirpar. Ramón Pané subraya que todo lo referido en cuanto a sus creencias y prácticas idólatras "lo creen hasta hoy... Y esto lo creen todos en general". Por lo que concluye su relación con una advertencia sobre

lo que es necesario hacer para que se hagan todos cristianos. Y verdaderamente que la isla tiene gran necesidad de gente para castigar a los señores cuando son merecedores de ello [y] dar a conocer a aquellos pueblos las cosas de la santa fe católica y adoctrinarlos en ella; porque no pueden y no saben oponerse (48, énfasis mío).

Así, el autor no solo juzgó necesario contar con más miembros eclesiásticos para evangelizar, pero sobre todo solicitó un mayor número de autoridades civiles para aplicar los castigos. El castigo que el extirpador aplica - por medio de las autoridades civiles - es una consecuencia merecida del idólatra, ya que Dios así lo dispone: "Y destruiré vuestros altos, y talaré vuestras imágenes, y pondré vuestros cuerpos muertos sobre los cuerpos muertos de vuestros ídolos" (Levítico 26:30). Entre los castigos que el idólatra merece por desobediencia están: la debilidad, la destrucción del producto (cosecha), las plagas, las guerras y la dispersión (Levítico 26:16-39).

El "pobre ermitaño Ramón Pané" afirma en su epílogo que la única utilidad que pretende con la labor emprendida de "saber y entender acerca de las costumbres y los ritos de los indios de La Española" es que "redund[e] en beneficio y servicio" del Señor (49). Según lo dictan las normas de su orden, su estudio va orientado a Dios. El autor, pues, concluye que su obra tiene como única mira el provecho del Señor, en otras palabras, que resulte de utilidad al fin evangélico. 


\section{CONSIDERACIONES FINALES}

Si bien esta obra ha resultado de gran valor para el campo de la antropología, como lo han sido las obras de otros misioneros (Sahagún y Motolinia, por ejemplo), no hay que olvidar, según advierte Baraibar (2011), su espacio de experiencia; es decir, no hay que dejar de tener en cuenta el objetivo, perspectiva y postura del autor. Todos estos evangelizadores tuvieron un común objetivo para su labor: erradicar los ritos indígenas e incorporar a los pobladores del Nuevo Mundo a la Cristiandad. Por tanto, si bien el manuscrito de Pané es una fuente valiosa para conocer la religión taína, no debe malinterpretarse como un intento antropológico. El mismo fray Ramón informa que las páginas de su relación presentan "las creencias e idolatrías de los indios" (3).

La palabra idolatría advierte al lector del siglo XVI que se trata, pues, de una negación al verdadero Dios. Según López Maguiña: Pané's attention to the antiquities of native culture was prompted less by an interest to understand it than by an attempt to prove evil influences (296). Por consiguiente, la finalidad del autor de la Relación no fue estudiar la diversidad cultural del taíno, sino aprehender su comportamiento religioso. En otras palabras, su objetivo fue recolectar idolatrías y, por tanto, su perspectiva y postura de extirpador deben ser tomadas en cuenta.

El autor ha conseguido presentar una relación comprensiva de las "antigüedades" de los indios: sus mitos y fábulas, sus prácticas rituales y costumbres, sus dioses locales y sus lugares sagrados. Mas, desde el mismo hecho de llamarlos antigüedades apunta a que es algo que no continúa -o no debe continuar - en el presente momento de la colonización y evangelización de las nuevas tierras.

La voz de Ramón Pané se esconde detrás de la pantalla del discurso oral nativo y su dizque "fidelidad" de lo recolectado y referido, con lo que el autor-narrador logra desaparecer en su texto como simple compilador de los mitos. En gran parte de la obra fray Ramón sigue la premisa de "a buen entendedor pocas palabras". Al transcribir la información taína, su perspectiva cristiana muchas veces está disimulada. No obstante, esta prevalece tras los usos de "dicen", "creen" y "no saben".

Además, en la Relación existen ciertos comentarios editoriales a las narraciones transcritas y a las vivencias experimentadas que dejan percibir una voz de corte examinador y censor que transmiten la postura del fraile autor. Esta es la voz del evangelizador Ramón Pané, quien no deja de actuar como extirpador y de proponer una contraofensiva a la idolatría vigente.

El fraile jerónimo no necesita formar parte de los debates de extirpación de idolatrías o de una campaña institucionalizada para saber cómo debe conducirse según lo dicta su fe y lo manda su hábito. Pané presenta una ideología monológica en su visión del taíno, sus creencias y prácticas, en cuanto su verdad se afirma y todo lo 
demás se niega. Su obra surca el camino de futuros evangelizadores e inaugura la empresa de erradicar las creencias nativas en el Nuevo Mundo. Por ello, Ramón Pané debe denominarse el primer extirpador de idolatrías de América.

\author{
Manhattanville College* \\ Spanish Department \\ 2900 Purchase Street Purchase, New York 10577 (USA) \\ marguerite.cattan@mville.edu
}

\title{
OBRAS CITADAS
}

Adorno, Rolena. "Overview". The Polemics of Possession in Spanish American Narrative. New Haven: Yale University Press, 2007. pp. 1-20.

Álvarez Palenzuela, Vicente Ángel. "Wyclif y Hus: La reforma heterodoxa." Clio y Crimen. 1 (2004) 241-259.

Aquinas, Thomas. Summa Theologice. Superstition and Irreverence. Vol. 40. Thomas F. O'Meara and Michael J. Duffy, eds and trans. London: Blackfriars, 1968.

Arrom, José Juan. "Estudio preliminar". Relación acerca de las antigüedades de los indios. México: Siglo XXI, 1988. pp. xi-xxv.

-"Fray Ramón Pané, autor del primer libro escrito en las Indias", Anales de la literatura Hispanoamericana, 9 (1980). Disponible en: http://revistas.ucm.es/index.php/ALHI/article/view/ALHI8080110015A

-“Fray Ramón Pané, descubridor del hombre americano". Thesaurus. 47:2 (1992) 337-353.

Baraibar, Álvaro. "La Naturaleza en el discurso indiano: la construcción de un espacio de experiencia americano". B. Castany et al., eds. Tierras prometidas. De la Colonia a la Independencia, Bellaterra. Barcelona: Centro para la Edición de los Clásicos Españoles, 2011, pp. 9-30.

Bula Inter Caetera. Donación del papa Alejandro VI a los Reyes Católicos, 3 de mayo de 1493. Disonible en:

http://www.biblioteca.tv/artman2/publish/1493_258/Primera_Bula_Inter_caete ra_de_Donaci_n_del_Papa_Al_443.shtml

Campos y Fernández de Sevilla, $\bar{F}$. Javier. "Los reyes de España y la Orden de San Jerónimo". Carlos $V$ en Yuste. Muerte y gloria eterna. Catálogo de la Exposición, Monasterio de Yuste, 2008. Madrid 2008, pp. 113-143. Disponible en:

http://www.javiercampos.com/files/Los\%20Reyes\%20de\%20Espana $\% 20 y \% 2$ 0La\%20Orden $\% 20 \mathrm{de} \% 20 \mathrm{San} \% 20 \mathrm{Jeronimo.PDF}$

Cattan, Marguerite. "Ramón Pané y su mundo monológico". Dialogía 7 (2013) 196-226. 
Colón, Cristóbal. Carta a los Reyes Católicos, 4 de marzo 1493. Disponible en: http://www.biblioteca.tv/artman2/publish/1493_258/Carta_de_Crist_bal_Col_ n_a_los_Reyes_Cat_licos_anu_444.shtml Carta a los Reyes Católicos, abril-mayo 1494. Disponible en: http://www.biblioteca.tv/artman2/publish/1494_259/Carta_de_Crist_bal_Col_ n_a_los_Reyes_Cat_licos_439.shtml

De Anglería, Pedro Mártir. Décadas del Nuevo Mundo. Madrid: Ediciones Polifemo, 1989.

Dussel, Enrique. Historia de la Iglesia en América Latina. Medio milenio de coloniaje y liberación (1492-1992). Madrid: Mundo Negro, 1992. pp. 79-134.

García, Juan Carlos. "El juicio contra Francisco de Ávila y el inicio de la extirpación de la idolatría en el Perú." 2013. pp. 1-24. Disponible en:

http://www.idolatrica.com/wp-content/uploads/2011/04/Avila-y-laextirpación-por-jc-garcia.pdf

González Echevarría, Roberto. Myth and Archive. A Theory of Latin American Narrative. Cambridge: Cambridge University Press, 1990.

Gruzinski, Serge. La guerra de las imágenes. De Cristóbal Colón a "Blade Runner" (1492-2019). México: Fondo de Cultura Económica, 1995.

Las Casas, Bartolomé de. "Apéndice: Algunos capítulos de la Apologética historia". En Historia de las indias. Libro III. Madrid: Imprenta de Miguel Ginesta, 1875. pp. 237-555.

León Guerrero, $\mathrm{M}^{\mathrm{a}}$ Montserrat. "Los compañeros de don Cristóbal Colón en su segundo viaje, pp. 1-20. Disponible en: www.adghn.org/confe/2004/colon_segundo_viaje.pdf

------El segundo viaje colombino. Tesis de doctorado. Universidad de Valladolid, 2000. Disponible en: http://www.cervantesvirtual.com/buscador/?q=el+segundo+viaje+colombino\# posicion

López-Baralt, Mercedes. "Fray Ramon Pané quinientos años después: una mirada actual al texto fundacional caribeño". En: Beatriz González Stephan y Lucía Helena Costigan. Crítica y descolonización: el sujeto colonial en la cultura latinoamericana. Caracas: Academia Nacional de la Historia, 1992, pp. 67-86.

-------Para decir al Otro. Literatura y antropología en nuestra América. Madrid: Iberoamericana, 2005. Cap. IV "El mito taíno: Levi-Strauss en las Antillas". pp. 83-115.

López Maguiña, Santiago. "Colonial Writing and Indigenous Discourse in Ramón Pané's Relación acerca de las antigüedades de los indios". En: René Jara y Nicholas Spadaccini. Amerindian Images and the Legacy of Columbus. Minneapolis: University of Minnesota Press, 1992, pp. 291-311. 
Mitre Fernández, Emilio. "Cristianismo medieval y herejía”. Clio \&Crimen 1 (2004) 23-42. Disponible en:

https://www.durango-udala.net/portalDurango/RecursosWeb/

DOCUMENTOS/1/0_418_1.pdf

Orden de San Jerónimo. Disponible en: www3.planalfa.es/msmparral

Pané, Ramón. Relación acerca de las antigüedades de los indios. México: Siglo XXI, 1988.

Rodríguez Luna, David. "Algunos aspectos para el estudio de la caridad en la Orden de San Jerónimo". Seminario conciliar. pp. 923-949. Disponible en: http://dialnet.unirioja.es/servlet/articulo?codigo $=2821956$

Santa Biblia. Antiguo y Nuevo Testamento. Antigua versión de Casiodoro de Reina (1569), revisada por Cipriano de Valera (1602) y cotejada posteriormente con diversas traducciones, y con los textos hebreo y griego. Buenos Aires: Sociedad Bíblica Americana.

Sigüenza, fray José de. Historia de la Orden de San Jerónimo. Tomo I. Madrid: Bailly Bailliere e Hijos Editores, 1907.

Solodkow, David. "Brother Ramon Pane and the Ego preacher: ethnographic matrix, violence and fictionalization of another". Revista de Estudios Hispánicos. 42:2 (2008) 237-259. 